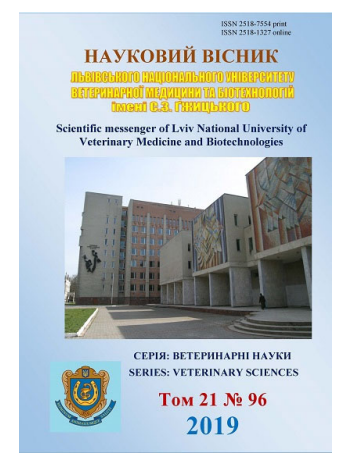

\author{
Науковий вісник Львівського національного університету \\ ветеринарної медицини та біотехнологій імені С.3. Гжицького. \\ Серія: Ветеринарні науки
}

\author{
Scientific Messenger of Lviv National University \\ of Veterinary Medicine and Biotechnologies.
} Series: Veterinary sciences

ISSN 2518-7554 print ISSN 2518-1327 online doi: $10.32718 /$ nvlvet9632

http://nvlvet.com.ua

UDC 619:615.28:638.1

\title{
Efficiency of application of modern sanitation supplies in beekeeping
}

\author{
M.V. Leshchyshyn, I.V. Dvylyuk, M.M. Rykniuk \\ Stepan Gzhytskyi National University of Veterinary Medicine and Biotechnologies Lviv, Ukraine
}

Article info

Received 11.11.2019

Received in revised form 13.12 .2019

Accepted 16.12.2019

Stepan Gzhytskyi National University of Veterinary Medicine and Biotechnologies Lviv,

Pekarska Str., 50, Lviv, 79010, Ukraine. Tel.: +38-098-768-93-08 E-mail: mykhailo. leshchyshyn@gmail.com

\begin{abstract}
Leshchyshyn, M.V., Dvylyuk, I.V., \& Rykniuk, M.M. (2019). Efficiency of application of modern sanitation supplies in beekeeping. Scientific Messenger of Lviv National University of Veterinary Medicine and Biotechnologies. Series: Veterinary sciences, 21(96), 185-191. doi: $10.32718 /$ nvlvet 9632
\end{abstract}

The article presents the results of studies of the effect of commercial disinfectants registered in Ukraine and allowed for use in beekeeping, as well as a comparative characteristic of their effectiveness in the disinfection of wooden beehive structures. The research was conducted on the basis of the departments of hygiene, sanitation and general veterinary prevention and technology of production and processing of products of small animals of the Lviv National University of Veterinary Medicine and Biotechnology named after S.Z. Gzhytskyi and SLW "Biolab" Food and Veterinary Diagnostic Laboratory (Ostroda, Poland). For research in the spring and summer period 4 groups of test objects were formed on the principle of analogues. Distilled water was used to control disinfection (test group 1). In the second experimental group for disinfection used "Brovadez-20" (active substance benzalkonium chloride 0.5\%), in the third experimental group zpy "Vetox-1000" (active substance hypochlorite 0.3\%) and in the fourth experimental group - "Sumerian silver" (active ingredient of 10\% citrate of Argentum citrate). In a comparative analysis of the effectiveness of the disinfectants of the II, III and IV groups, the growth of gram-positive (Streptomyces badius, Curtobakterium) and gram-negative bacteria (Xanthomonas hyacinthi, Pseudomonas alcaligenes, Acidovorax defluvii) was detected, respectively, among the endophores. In the current literature, information on the threat to the health of the honey bee detected by microorganisms is missing. According to the research, certain differences between the effectiveness of disinfectants have been established. It was found that the total microbial number (BMI) was $0.15 \%$ in group II, $0.16 \%$ in group III and up to $0.10 \%$ in group IV relative to control. It was found that the Sumer silver disinfectant at $10 \%$ concentration provides the best bactericidal effect $(P<0.001)$. In a comparative intergroup analysis of the effectiveness of disinfectants, it was found that in the conditions of the experiment, the level of bactericidal activity was the highest in the experiment with the SMC in the case of the use of "Sumer silver" was 32.3\% and $34.4 \%$ better compared to "Brovades-20" and "Vetox-1000", respectively. The use of "Sumerian silver" allows you to get the desired result 10 and 4 times faster than the disinfectants "Brovadez-20" and "Vetox-1000" respectively.

Key words: honey bees (Apis mellifera), hive, desinfection, nanopartale.

\section{Ефективність застосування сучасних санітарно-гігіснічних засобів у бджільництві}

\author{
М.В. Лещишин, І.В. Двилюк, М.М. Рихнюк
}

Львівський національний університет ветеринарної медицини та біотехнологій імені С.3. Гжиџького, м. Львів, Україна

У статті наведено результати досліджень дії комериійних дезінфектантів, зареєстрованих в Україні та дозволених для використання у бджільництві, а також наведена порівняльна характеристика їх ефективності за дезінфекиії дерев'яних конструкцій вуликів. Дослідження проводили на базі кафедр гігієни, санітарї та загальної ветеринарної профілактики та технології виробництва і переробки продукиії дрібних тварин Львівського національного університету ветеринарної медицини та біотехнологій 
імені С.3. Гжицького та ветеринарної діагностичної лабораторії SLW “Biolab” (м. Оструда, Польщза). Для досліджень у веснянолітній період на 4 групах тест-об'єктів сформованих за принцииом аналогів. Для контролю дезінфекиії (I дослідна група) використовували дистильовану воду. У ІІ дослідній групі для дезінфекиії використовували “Бровадез-20” (діюча речовина бензалконію хлорид 0,5\%), у III дослідній групі - “Ветокс-1000” (діюча речовина натрію гіпохлорит 0,3\%) і у IV дослідній групі - “Шумерське срібло” (діюча речовина цитрат Аргентуму ичитрат Курпуму 10\%). За порівняльного аналізу ефективності дезінфікуючих засобів II, III і IV груп було виявлено ріст грампозитивних (Streptomyces badius, Curtobakterium) та грамнегативних бактерій (Хапthoтопаs hyacinthi, Pseudomonas alcaligenes, Acidovorax defluvii) відповідно серед спороутворючих мікрооганізмів було виявлено (Вас. епdоphyticus). У сучасній літературі інформаџія про загрозу для здоров'я медоносної бджоли виявлених мікроорганізмів відсутня. За результатами досліджень встановлено певні міжгрупові різниці ефективності дезінфікуючих засобів. Виявлено, цо загальне мікробне число (ЗМЧ) на 0,15\% у II групі, 0,16\% у III групі та до 0,10\% у IV групі відносно контролю. Встановлено, щзо дезінфікуючий засіб “Шумерське срібло” у 10\% концентрачї забезпечує кращчии бактерииидний ефект (P < 0,001). За порівняльного міжгрупового аналізу ефективності дезінфікуючих засобів встановлено, щуо в умовах експерименту за рівнем ЗМЧ найвищий рівень бактерицидної активності був виражений у випадку застосування “Шумерського срібла” був крашим на 32,3\% та 34,4\% відносно до “Бровадезу-20” та “Ветоксу-1000” відповідно. Застосування “Шумерського срібла” дозволяє отримати бажаний результат в 10 та 4 рази швидше у порівнянні з дезінфікуючими засобами “Бровадез-20” та “Ветокс-1000” відповідно.

Ключові слова: медоносні бджоли (Apis mellifera), вулик, дезінфекція, нанопрепарати

\section{Вступ}

Загальновідомо, що проблема збереження здоров’я медоносних бджіл щораз гостріше постає перед спеціалістами та науковцями цілого світу. Зокрема, рівень антропогенного навантаження як на бджолину сім'ю, так і на середовище іï існування настільки значний, що ставить під загрозу існування медоносної бджоли (Apis mellifera L), як виду (Vishchur et al., 2016; Kulhanek et al., 2017; Kovalskyi et al., 2018; Vishchur et al., 2019; Kovalchuk et al., 2019). Додатковим негативним фактором на фоні антропогенного навантаження є виникнення, розвиток та поширення захворювань бджіл різноманітної етіології.

Зокрема, в останнє десятиліття простежується загрозлива тенденція масової загибелі бджіл світового масштабу, яку характеризують як колапс бджолиної сім'ї (синдром CCD) (van Engelsdorp et al., 2017). Ceред основних причин масової загибелі медоносних бджіл виділяють: інфекційні та інвазійні хвороби, застосування пестицидів та інших хімічних засобів у рослинництві, експлуатація бджіл в умовах монокультур, безконтрольні промислові переміщення бджолиних сімей з одного регіону в другий (Chen et al., 2008; Guzmán-Novoa et al., 2010; Cloyd, 2019). Важливим розділом превентивно-профілактичних робіт у системі забезпечення здоров'я медоносних бджіл посідає комплекс санітарно-гігієнічних заходів, зокрема, дезінфекція (Romanchenko et al., 2015). Серед відомих на сьогоднішній день дезінфікуючих засобів, які використовуються у бджільництві та найбільш уживані у світовій практиці є препарати на основі формальдегіду $65 \%$, перекису водню $20 \%$, оцтової кислоти $10 \%$ та молочної кислоти 5\%. В основу їх розробки покладений принцип універсальності та ефективності дії на широкий спектр патогенної та умовно-патогенної мікрофлори. Проте інформація щодо безпечності дезінфікуючих засобів як для організму медоносних бджіл і їх продукції, так і для довкілля, є досить обмеженою і вимагає більш ширшого висвітлення й вивчення. Серед зареєстрованих на ринку України та дозволених для застосування у бджільництві дезінфікуючих засобів $є$ лише препарати на основі безалконію хлориду, натрію гіпохлориту та наноформи цитрату Купруму і Аргентуму. Тому, в останні роки, 3 розвитком сучасних технологій синтезу хімічних засобів, зокрема, отриманих за допомогою нанотехнологій, виникає інтерес до вивчення їх дезінфікуючих властивостей (Rizzello \& Pompa, 2014). Наносполуки, в тому числі органічної природи, володіють високою хімічною активністю з вираженим антибактеріальним ефектом (Yegorova et al., 2014). Зокрема, наночастинки металів часто розглядаються як альтернативні протимікробні агенти (Besinis et al, 2014). За прямого контакту 3 бактеріальними мембранами, виникають механічні пошкодження або окислювальний стрес (Peng et al., 2017; Slavin et al., 2017). Відома велика кількість робіт, спрямованих на вивчення антибактеріальних властивостей наночастинок металів (Morones et al., 2005; Shahverdi et al., 2007; Natarajan et al., 2010; Lara et al., 2011; Kisterskaya et al., 2012; Ouay \& Stellacci 2015; Vimbela et al., 2017), як агентів, що володіють широким спектром антибактеріальної активності без розвитку резистентності мікроорганізмів.

Тому, метою наших досліджень було провести санітарно-гігієнічну оцінку засобів, які використовуються у бджільництві щодо мікрофлори внутрішньої частини дерев'яних вуликів.

\section{Матеріал і методи досліджень}

Дослідження проводили на базі кафедр гігієни, санітарії та загальної ветеринарної профілактики, технології виробництва і переробки продукції дрібних тварин, нормальної та патологічної морфології і судової ветеринарії Львівського національного університету ветеринарної медицини та біотехнологій імені С.3. Гжицького та ветеринарної діагностичної лабораторії SLW “Biolab” (м. Оструда, Польща).

У дослідження включили дезінфікуючі засоби, зареєстровані на ринку України та дозволені для застосування у бджільництві - Бровадез-20, Ветокс-1000 і Шумерське срібло.

"Бровадез-20" - дезінфектант, який містить діючу речовину - бензалконію хлорид і використовується для дезінфекції вуликів, рамок та іншого обладнання на пасіках. Препарат застосовують у вигляді робочих розчинів, які готують шляхом змішування концентрату 3 нехлорованою водою, шляхом зрошування. У бджільництві використовується робочий розчин у 
0,5\% (5 мл на 1 л води). Мінімальний час експозиції$10-12$ год.

“ВетОкс-1000" - дезінфектант, який містить діючу речовину-натрію гіпохлорит. Механізм дії базується на утворені атомарного кисню, який є сильним окисником. Застосовують для дезінфекції вуликів, стільників та іншого пасічницького інвентарю шляхом зрошування. Перед застосуванням препарат розводять у співвідношенні 1 частина маточного розчину "Ветокс-1000” і 3 частини нехлорованої питної води, що дозволяє отримати дезінфектант із вмістом діючої речовини 0,3\%. Мінімальний час експозиції - 4 год.

“Шумерське срібло" представляє собою комплексний препарат на основі наноформ (розміром молекули - 50 мкм) цитрату Купруму та цитрату Аргентуму у рівному співвідношенні $(1: 1)$. Ефективний дезінфікуючий засіб проти більшості типів патогенних мікроорганізмів. Засіб застосовують для дезінфекції у вигляді робочих розчинів шляхом зрошування, які готують за допомогою змішування концентрату із нехлорованою питною водою (100 мл діючої речовини на 1 л води), що дозволяє отримати дезінфектант із вмістом діючої речовини $10 \%$ з мінімальним часом експозиції - 1 год.

Для визначення бактерицидної активності дезінфікуючих засобів було сформовано 4 групи тестоб'єктів: I дослідна група (дистильована вода). У II дослідній групі для дезінфекції використовували “Бровадез-20" (діюча речовина бензалконію хлорид 0,5\%), у III дослідній групі - “Ветокс-1000” (діюча речовина натрію гіпохлорит 0,3\%) і у IV дослідній групі - "Шумерське срібло" (діюча речовина цитрат Аргентуму цитрат Курпуму 10\%). Попередню підготовку тест-об'єктів здійснювали шляхом механічного очищення, після чого провели їх дезінфекцію методом зрошування за допомогою обприскувача Росинка-2 (рис. 1).

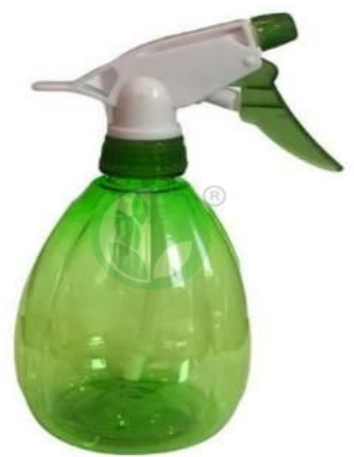

Рис. 1. Обприскувач Росинка-2

Тест-об'єктом була обрана внутрішня поверхня багатокорпусного вулика. Після експозиції дезінфікуючих засобів, яка, відповідно до настанови, складала 10-12 год для II, 4 год для III і 1 год для IV груп, здійснювали контроль якості їх дезінфекції. Площу змиву $100 \mathrm{~cm}^{2}(10 \times 10 \mathrm{~cm})$ обмежували за допомогою трафарету. Для відбору проб використовували стерильні транспорті пробірки “Волес" з 0,9\% розчином $\mathrm{NaCl}$ (2 мл) (рис. 2).

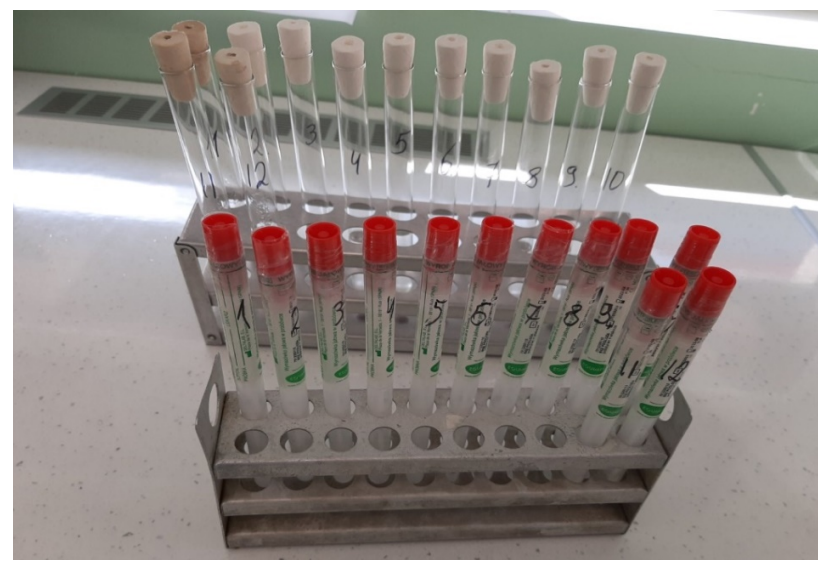

Рис. 2. Стерильні транспорті пробірки "Волес"

Для визначення загального мікробного числа (ЗМЧ) використовували поживне середовище триптон соєвий агар (TSA). Період інкубації становив 24 год, при відсутності росту інкубацію продовжували до 48 год за температури $+37 \pm 1{ }^{\circ} \mathrm{C}$.

Для виявлення видів роду Streptococcus i Staphylococcus застосовували кров'яний агар. Період інкубації становив 24 год, при відсутності росту інкубацію продовжували до 48 год за температури $+37 \pm 1{ }^{\circ} \mathrm{C}$.

Для виявлення грамнегативних бактерій використовували агар McConkey з подальшим їх диференціюванням за результатами зброджування лактози. Період інкубації становив 24 год, при відсутності росту інкубацію продовжували до 48 год за температури $+37 \pm 1^{\circ} \mathrm{C}$.

3 метою виявлення грибів використовували агар Сабуро. Період інкубації становив 48 год за температури $+37 \pm 1{ }^{\circ} \mathrm{C}$.

Після посіву досліджувані проби інкубували в термостаті Security, 382 L, Heratherm, Thermo Fisher. Підрахунок ЗМЧ з розрахунку на $1 \mathrm{~cm}^{3}$ змивів за загально прийнятою методикою (Yakubchak et al., 2005) та ix подальшу ідентифікацію провели на масспектрометрі Microflex LT/SH MALDI-MS System. Для інтерпретації даних використовували значення бальної шкали діапазоном 2,00-3,00 - високий рівень ідентифікації, символи $(+++)$, зелений колір; 1,70 низький рівень ідентифікації (+), жовтий колір; 0,001,69 - відсутність ідентифікації організму (-), червоний колір.

\section{Результати та їх обговорення}

За результатами досліджень антимікробної дії дезінфектантів, наведеними у (табл. 1), встановлено, що за умов застосування дезінфікуючого засобу “Шумерське срібло” спостерігався менший ріст мікроорганізмів у порівнянні з іншими досліджуваними засобами. Так, ЗМЧ у змивах із поверхонь тест-об' єктів складало $2,00 \times 10^{4} \mathrm{KУO} / \mathrm{cm}^{3} \quad$ у контрольній групі, $3,13 \times 10^{1} \mathrm{KУO} / \mathrm{cm}^{3}(\mathrm{P}<0,001)$ у II дослідній групі, $3,26 \times 10^{1} \mathrm{KУO} / \mathrm{cm}^{3}(\mathrm{P}<0,001)$ у III дослідній групі та у IV дослідній групі не перевищувало $2,10 \times 10^{1} \mathrm{KУO} / \mathrm{cm}^{3}$ $(\mathrm{P}<0,001)$. 


\section{Таблиця 1}

Динаміка мікробіологічних показників змивів з внутрішніх стінок вуликів за умов застосування дезінфектантів $(\mathrm{M} \pm \mathrm{m}, \mathrm{n}=3)$

\begin{tabular}{|c|c|c|c|c|c|}
\hline Групи & Засоби & Концентрація р-ну, \% & ЗМЧ, КУО/ см ${ }^{3}$ змиву & Динаміка контамінації, \% & Експозиція \\
\hline I & Контроль $\mathrm{H}_{2} \mathrm{O}$ & - & $2,00 \times 10^{4} \pm 5,77$ & - & - \\
\hline II & Бровадез-20 & $0,5 \%$ & $3,13 \times 10^{1} \pm 4,37 * * *$ & II-I 0,15 & 10-12 год \\
\hline III & Ветокс-1000 & $0,3 \%$ & $3,26 \times 10^{1} \pm 4,48^{* * *}$ & $\begin{array}{l}\text { III-I } 0,16 \\
\text { III-II } 103\end{array}$ & 4 год \\
\hline IV & $\begin{array}{c}\text { Шумерське } \\
\text { Срібло }\end{array}$ & $10 \%$ & $2,10 \times 10^{1} \pm 2,08^{* * *}$ & $\begin{array}{c}\text { IV-I } 0,10 \\
\text { IV-II } 67,70 \\
\text { IV-III } 65,60\end{array}$ & 1 год \\
\hline
\end{tabular}

Примітка: *-P $<0,05-0,02 ; * *-\mathrm{P}<0,01 ; * * *-\mathrm{P}<0,001$

Контроль якості дезінфекції показав незначну різницю ефективності дезінфікуючої дії, яка була вищою на 3\% у III дослідній групі порівняно з II. Дія дезінфектантів призводила до зниження ЗМЧ до 0,15\%, 0,16\% і 0,10\% відповідно, у II, III i IV групах порівняно до контролю. Серед досліджуваних дезінфікуючих засобів кращі показники ефективності дезінфекції дерев'яних поверхонь вуликів спостерігалася у IV дослідній групі, де застосовували дезінфікуючий засіб “Шумерське срібло”. Встановлено, що за дезінфекції дерев'яних поверхонь тест-об'єктів найкращий бактерицидний ефект у IV групі одноразового застосування дезінфікуючих засобів був на $32,3 \%$ та $34,4 \%$ біль- шим, ніж у II та III групах відповідно. Отримані результати щодо ідентифікації мікрофлори до і після обробки досліджуваними дезінфікуючими засобами за допомогою мас-спектрометра показали, що у контрольній групі знаходиться значно більше різноманіття ідентифікованих мікроорганізмів, ніж у досліджуваних групах.

Ідентифікація мікроорганізмів у змивах тестоб'єктів за дії дезінфікуючого засобу “Бровадез-20” у $0,5 \%$ концентрації було виявлено грампозитивні (Streptomyces badius), грамнегативні (Xanthomonas hyacinthi) та спороутворюючі мікроорганізми (Bac. endophyticus) (рис. 3).

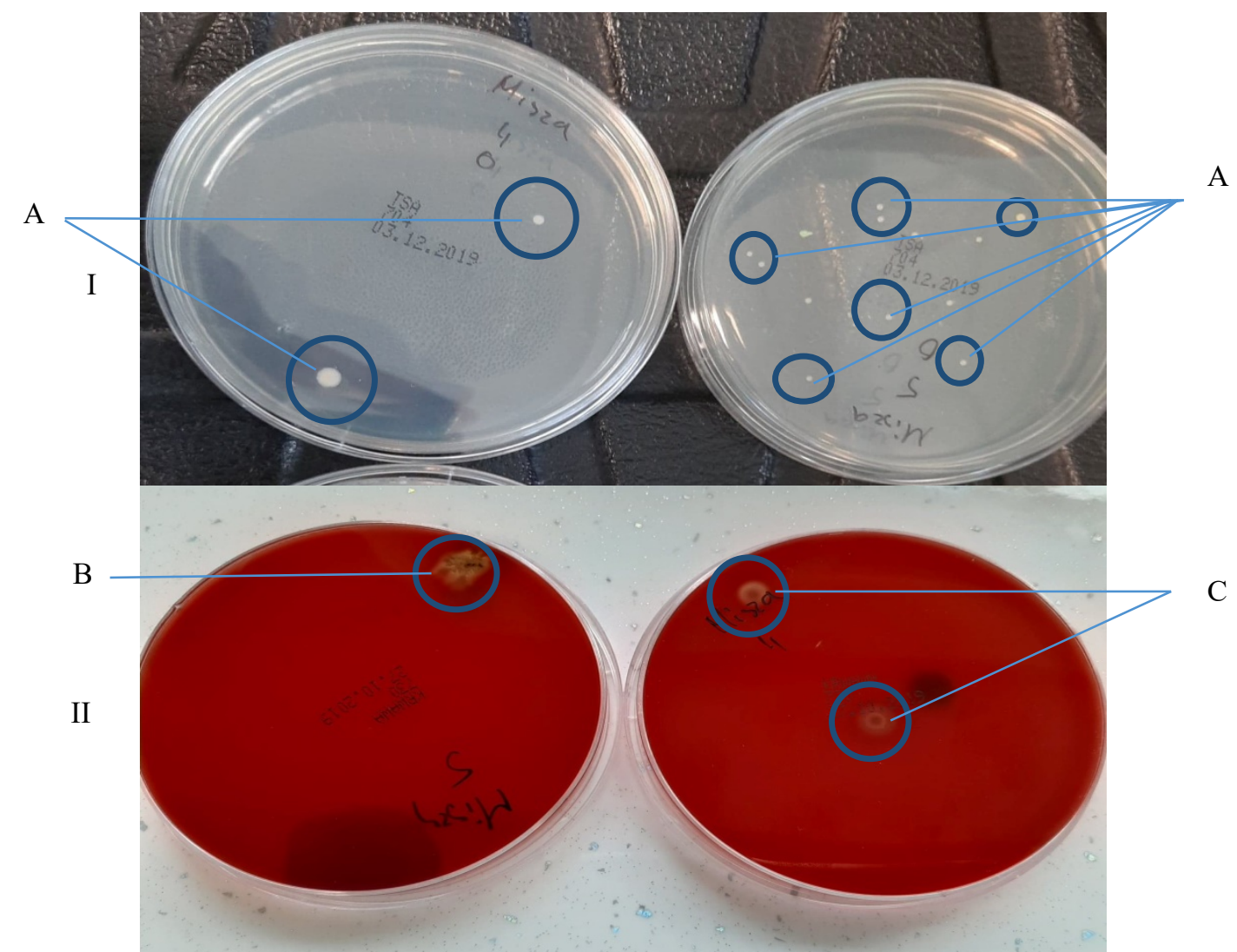

Рис. 3. I поживне середовище (TSA), II поживне середовище кров'яний агар. Ріст А (Xanthomonas hyacinthi) В (Streptomyces badius), та C (Bac. endophyticus) на внутрішній поверхні вуликів

Серед ізольованих культур у тест-об'єктах III групи за дії 0,3\% дезінфікуючого засобу "Ветокс-1000" було виявлено грампозитивні (Curtobakterium) та грамнегативні мікроорганізми (Pseudomonas alcaligenes) (рис. 4). 
Серед ізольованих культур у тест-об'єктах IV групи за дії 10\% дезінфікуючого засобу "Шумерське срібло" було виявлено грамнегативні мікроорганізми (Acidovorax defluvii) (рис. 5).

Виявлені культури мікроорганізмів після проведення дезінфекції з різних груп широко поширені у природі і звичайним середовищем їхнього існування $\epsilon$ грунт, поверхня рослин та внутрішня тканина здорових рослин. У сучасній літературі інформація про загрозу для здоров'я медоносної бджоли виявлених мікроорганізмів відсутня.
Також слід відмітити, що для досягнення бажаного результату період експозиції дезінфікуючих засобів становив 10 год, 4 год і 1 год у II, III i IV групах відповідно.

Порівняльний аналіз періоду експозиції вказує на швидкий період дезінфікуючої дії у 10 разів за умов застосуванні "Шумерського срібла" у порівнянні 3 "Бровадезом-20" та у 4 рази за умов застосуванні "Ветокс-1000".

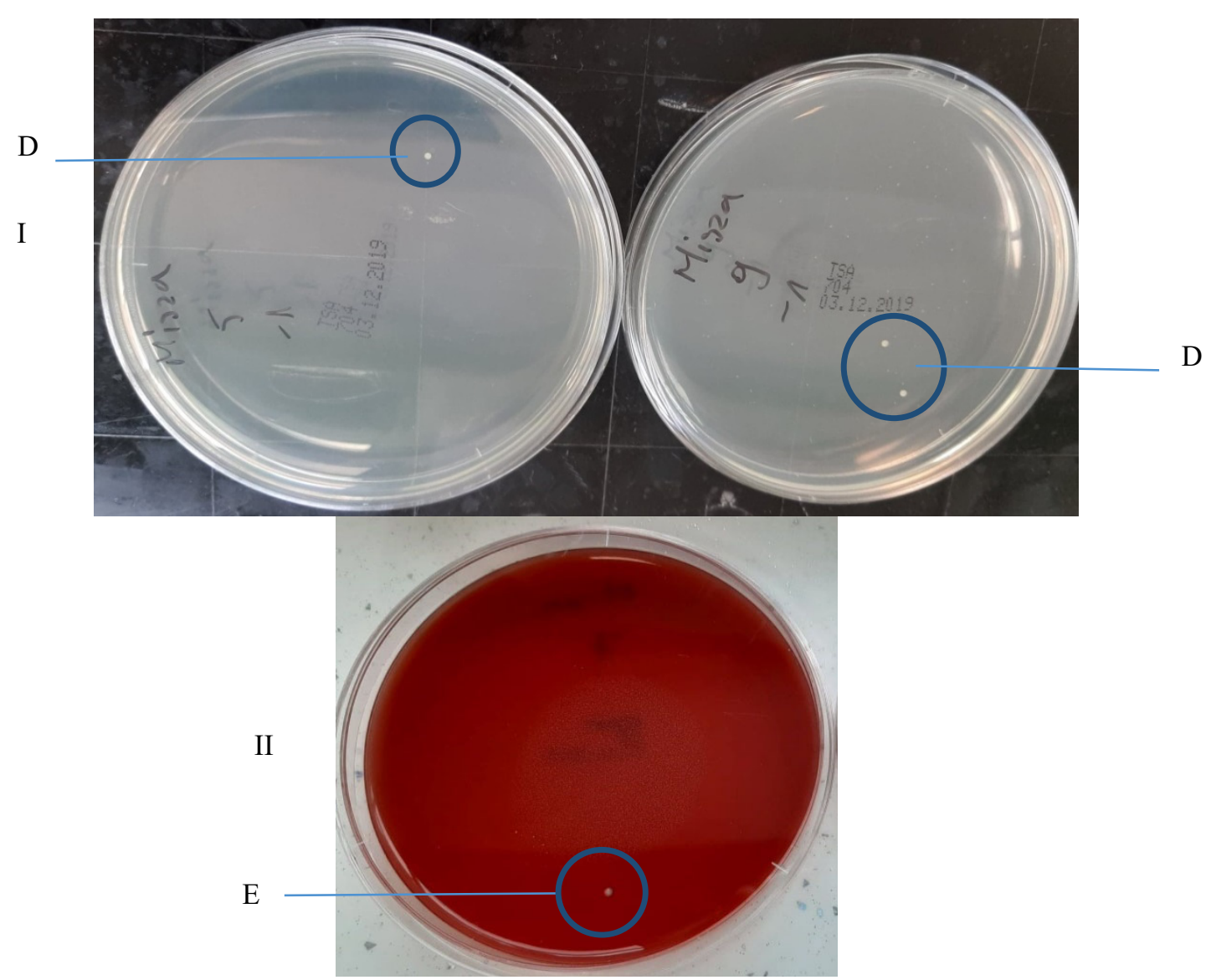

Рис. 4. I поживне середовище (TSA), II поживне середовище кров’яний агар. Ріст D (Pseudomonas alcaligenes) та Е (Curtobakterium) з внутрішньої поверхні вуликів

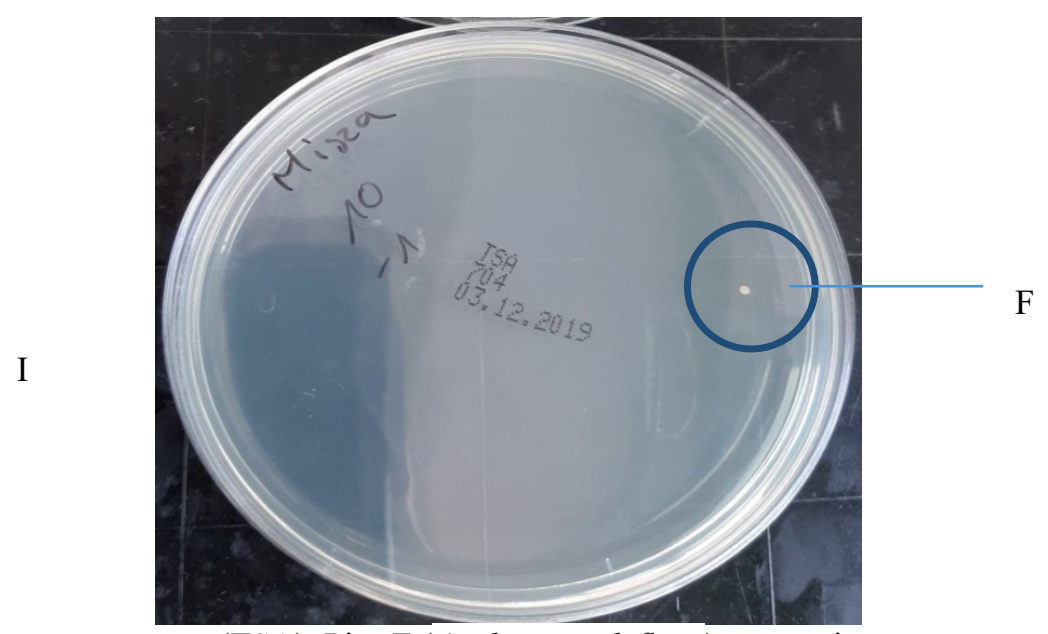

Рис. 5. І поживне середовище (TSA). Ріст F (Acidovorax defluvii) з внутрішньої поверхні вуликів 


\section{Висновки}

1. За порівняльного аналізу ефективності дезінфікуючих засобів II, III і IV груп було виявлено ріст грампозитивні (Streptomyces badius, Curtobakterium), грамнегативні бактерії (Xanthomonas hyacinthi, Pseudomonas alcaligenes, Acidovorax defluvii) та спороутворюючі мікроорганізми (Bac. endophyticus) відповідно.

2. Проведені дослідження показали, що ефективність засобів II, III та IV груп становить 99,85\%, 99,84\% та 99,90\% відповідно, порівняно з контролем та характеризується високою достовірністю отриманих результатів ( $\mathrm{P}<0,001)$, що вказує на їх високу бактерицидну активність.

3. За порівняльного міжгрупового аналізу ефективності дезінфікуючих засобів встановлено, що в умовах експерименту за рівнем ЗМЧ найвищий рівень бактерицидної активності був виражений у випадку застосування "Шумерського срібла" був кращим на $32,3 \%$ та 34,4\% відносно до "Бровадезу-20" та "Ветоксу-1000" відповідно.

4. Застосування "Шумерського срібла" дозволяє отримати бажаний результат в 10 та 4 рази швидше у порівнянні з дезінфікуючими засобами "Бровадез-20" та "Ветокс-1000" відповідно.

Таким чином санітарно-гігієнічна оцінка окремих показників досліджуваних дезінфікуючих засобів вказують на кращі дезінфікуючі властивості “Шумерського срібла".

\section{References}

Besinis, A., De Peralta, T., \& Handy, R. (2014).The antibacterial effects of silver, titanium dioxide and silica dioxide nanoparticles compared to the dental disinfectant chlorhexidine on Streptococcus mutans using a suite of bioassays. Nanotoxicology, 8(1), 116. doi: $10.3109 / 17435390.2012 .742935$.

Chen, Y., Evans, J., Smith, B., \& Pettis, J. (2008). Nosema ceranae is a long-present and wide-spread microsporidian infection of the European honey bee (Apis mellifera), in the United States. Invertebrate Pathology, 97(2), 186188. doi: 10.1016/j.jip.2007.07.010.

Cloyd, R. (2019). Effects of Pesticides and Adjuvants on the Honey Bee, Apis mellifera. doi: 10.5772/ intechopen.89082.

Franci, G., Falanga, A., Galdiero, S., Palomba, L., Rai, M., Morelli, G., \& Galdiero, M. (2015). Silver nanoparticles as potential antibacterial agents. Molecules, 20(5), 8856-8874. doi: 10.3390/molecules20058856.

Gurunathan, S., Han, J.W., Kwon, D.N., \& Kim, J.H. (2014) Enhanced antibacterial and anti-biofilm activities of silver nanoparticles against Gram-negative and Gram-positive bacteria. Nanoscale Res Lett, 9(1), 373. doi: 10.1186/1556-276X-9-373.

Guzmán-Novoa, E., Eccles, L., Calvete, Y., Mcgowan, J., Kelly, P., \& Correa-Benítez, A. (2010). Varroa destructor is the main culprit for the death and reduced populations of overwintered honey bee (Apis mellifera) colonies in
Ontario. Canada Apidologie, 41(4), 443-450. https://link.springer.com/article/10.1051/apido/2009076.

Kisterskaya, L., Sadokhin, V., \& Sadokhin, V. (2012). Biosovmestimyye dezinfektanty novogo pokoleniya na osnove nanoserebra. International Science and Technology Days Poland, 1, 53-59. http://www.nanoindustry.su/files/article_pdf/2/article_ 2593_552.pdf.

Kovalchuk, I., Dvylyuk, I., Lecyk, Y., Dvylyuk, I., \& Gutyj, B. (2019). Physiological relationship between content of certain microelements in the tissues of different anatomic sections of the organism of honey bees exposed to citrates of argentum and cuprum. Regulatory Mechanisms in Biosystems, 10(2), 177181. doi: $10.15421 / 021926$.

Kovalskyi, Yu., Gucol, A., Gutyj, B., Sobolev, O., Kovalska, L., \& Mironovych, A. (2018). Features of histolism and hystogenesis in the vital temperature range in the organism of honey bee (Apis mellifera L.) in the postembrional period. Ukrainian Journal of Ecology, 8(2), 301-307. doi: 10.15421/2018_342.

Kulhanek, K., Steinhauer, N., Rennich, K., Caron, D., Sagili, R., Pettis, J., Ellis, J., Wilson, M., Wilkes, J., Tarpy, D., Rose, R., Lee, K., \& Rangel, J. (2017). A national survey of managed honey bee 2015-2016 annual colony losses in the USA. Journal of Apicultural Research ${ }_{2}$ 56(4), 328-340. doi: 10.1080/00218839.2017.1344496.

Lara, H., Garza-Trevino, E., Ixtepan-Turrent, L., \& Singh, D. (2011). Silver nanoparticles are broad-spectrum bactericidal and virucidal compounds. Nanobiotechnol, 9(30), 32. doi: 10.1186/1477-3155-9-30.

Morones, J., Elechiguerra, J., Camacho, A., Holt, K., Kouri, J., Ramírez, J., \& Yacaman, M. (2005). The bactericidal effect of silver nanoparticles. Nanotechnology, 16(10), 2346-2353. doi: 10.1088/0957$4484 / 16 / 10 / 059$.

Natarajan, K., Selvaraj, S., \& Ramachandra, M. (2010). Microbial production of silver nanoparticles. Nanomater. Biostruct, 5(1), 135-140. http://admin.umt.edu.pk/Media/Site/STD/FileManager /OsamaArticle/August2015/10august/135_Natarajan.p df.

Ouay, B., \& Stellacci, F. (2015). Antibacterial activity of silver nanoparticles: a surface science insight. Nano Today, 10(3), 339-354. doi: 10.1016/j.nantod.2015.04.002.

Peng, C., Zhang, W., Gao, H., Li, Y., Tong, X., Li, K., Zhu, X., Wang, Y., \& Chen, Y. (2017). Behavior and potential impacts of metal-based engineered nanoparticles in aquatic environments. Nanomaterials, 22(7), 21. doi: 10.3390/nano7010021.

Ramsey, S., Ochoa R., Bauchan G., Gulbronson C., Mowery J., Cohen A., Lim, D., Joklik, J., Cicero, J., Ellis, J., Hawthorne, D., \& vanEngelsdorp, D. (2019) Varroa Destructor Feeds Primarily on Honey Bee Fat Body Tissue and Not Hemolymph. Proceedings of the National Academy of Sciences, 116(5), 1792-1801. doi: 10.1073/pnas.1818371116.

Rizzello, L., \& Pompa, P. (2014). Nanosilver-based antibacterial drugs and devices: mechanisms, 
methodological drawbacks, and guidelines. Chem Soc Rev, 43(5), 1501-1518. doi: 10.1039/c3cs60218d.

Romanchenko, M., Masliy, I., Kundenko, M., Sanin, K., \& Tsekhmeyster, O. (2015). Doslidzhennya dezinfikuyuchoyi diyi UV u zabezpechenni zberezhennya biopotentsialu bdzholosimey. Tvarynnytstvo ta tekhnolohiyi kharchovykh produktiv, 223, 162-167. http://journals.nubip.edu.ua/index.php/Tekhnologiya/a rticle/view/5863 (in Ukrainian).

Shahverdi, A., Fakhimi, A., Shahverdi, H., \& Minaian, S. (2007). Synthesis and effect of silver nanoparticles on the antibacterial activity of different antibiotics against Staphylococcus aureus and Escherichia coli. Nanomedicine, 3(2), 168-171. doi: 10.1016/j.nano.2007.02.001.

Slavin, Y., Asnis, J., Häfeli, U., \& Bach, H. (2017). Metal nanoparticles: understanding the mechanisms behind antibacterial activity. Nanobiotechnology, 15, 65. doi: 10.1186/s12951-017-0308-z.

van Engelsdorp, D., Traynor, K.S., Andree, M., Lichtenberg, E.M., Chen, Y., Saegerman, C., \& Cox-Foster, D.L. (2017). Colony Collapse Disorder (CCD) and bee age impact honey bee pathophysiology. Plos One, 12(7), e0179535. doi:10.1371/journal.pone.0179535.

Vimbela, G., Ngo, S., Fraze, C., Yang, L., \& Stout, D. (2017). Antibacterial properties and toxicity from metallic nanomaterials. Nanomedicine, 12, 3941-3965. doi. 10.2147/IJN.S134526.

Vishchur, V.Y., Saranchuk, I.I., \& Gutyj, B.V. (2016). Fatty acid content of honeycombs depending on the level of technogenic loading on the environment. Visnyk of Dnipropetrovsk University. Biology, ecology, 24(1), 182-187. doi: 10.15421/011622.

Vishchur, V.Y., Gutyj, B.V., Nischemenko, N.P., Kushnir, I.M., Salata, V.Z., Tarasenko, L.O., Khimych, M.S., Kushnir, V.I., Kalyn, B.M., Magrelo, N.V., Boiko, P.K., Kolotnytskyy, V.A., Velesyk, T., Pundyak, T.O., \& Gubash, O.P. (2019). Effect of industry on the content of fatty acids in the tissues of the honey-bee head. Ukrainian Journal of Ecology, 9(3), 174-179.

Yakubchak, O., Khomenko, V., \& Bondar, T. (2005). Rekomendatsiyi shchodo sanitarnomikrobiolohichnoho doslidzhennya zmyviv $\mathrm{z}$ poverkhon' test-obyektiv ta obyektiv veterynarnoho nahlyadu i kontrolyu. K.: Vydavnychyy tsentr NAU (in Ukrainian).

Yegorova, Ye., Kubatiayev, A., \& Shvets, V. (2014). Biologicheskiye effekty nanochastits metallov. Nauka (in Russian). 